\title{
Comments on: “In Vitro Safety Pharmacology Profiling of Topical a-Adrenergic Agonist Treatments for Erythema of Rosacea"
}

\author{
Daniel Gil ${ }^{1}$
}

Published online: 4 August 2018

(c) The Author(s) 2018

We appreciate the opportunity to comment on the findings and claims from the study conducted by Piwnica et al. [1]. The study included two commercially available compounds, brimonidine and oxymetazoline, and suggested a risk of valvulopathy associated with oxymetazoline based on results from several in vitro assays. We found the study to be informative, but would like to clarify that the data cannot be extrapolated to determine a definitive risk to humans associated with the use of oxymetazoline, and in fact demonstrates very large safety margins, indicating that the risk, if any, is minimal.

In Fig. 1 of the study, Piwnica et al. [1] tested the ability of brimonidine and oxymetazoline to bind $\alpha$-adrenergic receptors, as well as 5-HT receptors. Using a pharmacological profiling assay that assessed in vitro binding activity, Piwnica et al. [1] showed that brimonidine was highly specific for the $\alpha_{2}$-adrenergic receptors, while oxymetazoline bound to a range of targets, including $\alpha_{1}$ - and $\alpha_{2}$-adrenergic receptors and 5-HT receptors. However, the concentration of oxymetazoline $(10 \mu \mathrm{M})$ used in this assay is markedly higher than what has been observed after topical treatment with oxymetazoline hydrochloride $(\mathrm{Hcl})$ cream in humans $[2,3]$. In fact, Piwnica et al. [1] referenced a phase II study by Kuang et al. [2] and stated that oxymetazoline was reported to have systemic concentrations of $0.4 \mathrm{nM}$ after topical treatment, which is 25,000 -fold lower than the $10 \mu \mathrm{M}$ used in their pharmacological profiling assay. Furthermore, the $0.4 \mathrm{nM}$ value reported by Piwnica et al. [1] was not correct as Kuang et al. [2] demonstrated that commercial strength once-daily $1 \%$ oxymetazoline had a mean steady-state maximum concentration $\left(C_{\max }\right)$ of $66.4 \mathrm{pg} / \mathrm{mL}$ (median weight of $0.34 \mathrm{~g}$ per application), which amounts to $0.22 \mathrm{nM}$ (sum of free and bound drug in plasma); this is almost half of what

Daniel Gil

dan@cellerityconsulting.com

1 Research Technologies and Portfolio, Allergan plc, Irvine, CA, USA
Piwnica et al. [1] reported for the systemic concentrations of oxymetazoline. The correct $C_{\max }$ of $66.4 \mathrm{pg} / \mathrm{mL}$ is $3.4-$ fold lower than the average $C_{\max }$ of $226 \mathrm{pg} / \mathrm{mL}$ observed from two single-dose studies conducted for Afrin nasal spray $(0.05 \%$ oxymetazoline) $[4,5]$, which has been safely used as an over-the-counter drug for over 40 years. Even if subjects apply up to $35 \%$ more grams per application of $1 \%$ oxymetazoline HCL cream compared with what was used in the phase II study (i.e. the most conservative estimate based on the highest median usage across the phase III studies [6-8]), the expected mean steady-state $C_{\max }$ would still be $<90 \mathrm{pg} /$ $\mathrm{mL}$, which is over 30,000-fold below the $10 \mu \mathrm{M}$ used in the pharmacological profiling assays.

The reported $\alpha_{1}$-adrenergic activity of oxymetazoline is consistent with a recent in vivo study, in which we demonstrated that brimonidine and oxymetazoline cause cutaneous vasoconstriction through different $\alpha$-adrenergic mechanisms-oxymetazoline primarily functioning through $\alpha_{1}$-adrenergic receptors, and brimonidine primarily functioning through $\alpha_{2}$-adrenergic receptors [9]. Notably, recent findings suggest $\alpha_{2}$ agonist activity at presynaptic or endothelial sites as one of several potential mechanisms responsible for the paradoxical erythema observed with brimonidine, resulting in vasodilation rather than vasoconstriction [10]. These results are in line with two statements recently released by the Medicines and Healthcare products Regulatory Agency in the UK noting the following risks associated with the use of brimonidine gel: risk for further exacerbation of rosacea, and risk of systemic $\alpha_{2}$-adrenergic cardiovascular effects $[11,12]$.

In Fig. 2 of the study, Piwnica et al. [1] compared brimonidine and oxymetazoline's $5-\mathrm{HT}_{2 \mathrm{~B}}$ agonist activities by measuring calcium flux in HEK-293 cells expressing recombinant $5-\mathrm{HT}_{2 \mathrm{~B}}$ receptors. They observed negligible $5-\mathrm{HT}_{2 \mathrm{~B}}$ agonist activity with brimonidine, while oxymetazoline showed a half maximal effective concentration $\left(\mathrm{EC}_{50}\right)$ of $15 \mathrm{nM}$. It is important to note that the $C_{\max }$ of $0.22 \mathrm{nM}$ observed in the in vivo study of Kuang et al. [2] is 68-fold 
lower than the value determined in the in vitro assay of Piwnica et al. [1] using a cell line overexpressing $5-\mathrm{HT}_{2 \mathrm{~B}}$, which is likely to exaggerate a drug's potency.

In Fig. 3 of the study, Piwnica et al. [1] selectively assessed oxymetazoline's ability to induce proliferation of mitral valvular interstitial cells in vitro. Increasing doses of oxymetazoline were used, which showed proliferative activity starting at $10 \mu \mathrm{M}$, along with a $1 \mu \mathrm{M}$ 'no observed effect level' (NOEL) that was $>4500$-fold higher than the $0.22 \mathrm{nM} C_{\max }$ value observed by Kuang et al. [2]. Piwnica et al. [1] then referenced a study by Huang et al. [13] that identified oxymetazoline among 26 other compounds with $5-\mathrm{HT}_{2 \mathrm{~B}}$ receptor agonist activity. In the study by Huang et al. [13], the known valvulopathogens-pergolide, dihydroergotamine, and cabergoline-caused cell proliferation at concentrations as low as $1 \mathrm{nM}$, while norfenfluramine (a previously identified $5-\mathrm{HT}_{2 \mathrm{~B}}$ receptor agonist) was active at $30 \mathrm{nM}$. Conversely, oxymetazoline showed proliferative activity at $1000 \mathrm{nM}$, which was comparable to the negative control ropinirole. We would like to point out again that this observed concentration of $1000 \mathrm{nM}$ is significantly higher than the $C_{\max }$ of $0.22 \mathrm{nM}$ from Kuang et al. [2], further highlighting the reduced risk associated with oxymetazoline. In sum, the data reported and cited by Piwnica et al. [1] demonstrate a large safety margin with the use of once-daily $1 \%$ oxymetazoline.

Acknowledgements Medical writing assistance was provided by William Kim, PhD, of Allergan plc, Irvine, CA, USA.

\section{Compliance with Ethical Standards}

Funding No funding was received for the preparation of this letter.

Conflicts of interest Daniel Gil, $\mathrm{PhD}$, is an employee of Allergan plc, Irvine, CA, USA.

Open Access This article is distributed under the terms of the Creative Commons Attribution-NonCommercial 4.0 International License (http://creativecommons.org/licenses/by-nc/4.0/), which permits any noncommercial use, distribution, and reproduction in any medium, provided you give appropriate credit to the original author(s) and the source, provide a link to the Creative Commons license, and indicate if changes were made.

\section{References}

1. Piwnica D, Pathak A, Schäfer G, Docherty JR. In vitro safety pharmacology profiling of topical $\alpha$-adrenergic agonist treatments for erythema of rosacea. Drugs R\&D. 2018;18(1):87-90.

2. Kuang A, DuBois J, Ahluwalia G, Zhang S. Clinical pharmacokinetics of oxymetazoline cream following topical facial administration for the treatment of erythema associated with rosacea. Poster presentation at American Academy of Dermatology Annual Meeting, 20-24 March 2015; San Francisco, CA.

3. Kuang A, DuBois J, Attar M, Ahluwalia G. Clinical pharmacokinetics of oxymetazoline cream following topical facial administration for the treatment of erythema associated with rosacea. J Drugs Dermatol. 2018;17(2):213-20.

4. Leyden JJ. Clinical Study Report V-101-ROSE-201 (data on file). Allergan plc; 2010.

5. DuBois JC. Clinical Study Report V-101-ROSE-205 (data on file). Allergan plc; 2012.

6. Hardas B. Clinical Study Report 199201-004 (data on file). Allergan plc; 2014.

7. Hardas B. Clinical Study Report 199201-005 (data on file). Allergan plc; 2015.

8. Hardas B. Clinical Study Report 199201-006 (data on file). Allergan plc; 2015.

9. Hsia E, Tian M, Gil D. Reduction of ultraviolet B light-induced erythema by oxymetazoline and brimonidine is mediated by different $\alpha$-adrenoceptors. Exp Dermatol. 2018;27(7):763-8.

10. Docherty JR, Steinhoff M, Lorton D, Detmar M, Schafer G, Holmes A, et al. Multidisciplinary consideration of potential pathophysiologic mechanisms of paradoxical erythema with topical brimonidine therapy. Adv Ther. 2016;33(11):1885-95.

11. Brimonidine gel (Mirvaso): risk of exacerbation of rosacea. https ://www.gov.uk/drug-safety-update/brimonidine-gel-mirvaso-riskof-exacerbation-of-rosacea. Accessed 30 Apr 2018.

12. Brimonidine gel (Mirvaso): risk of systemic cardiovascular effects; not to be applied to damaged skin. https://www.gov. uk/drug-safety-update/brimonidine-gel-mirvaso-risk-of-syste mic-cardiovascular-effects-not-to-be-applied-to-damaged-skin. Accessed 30 Apr 2018.

13. Huang XP, Setola V, Yadav PN, Allen JA, Rogan SC, Hanson $\mathrm{BJ}$, et al. Parallel functional activity profiling reveals valvulopathogens are potent 5-hydroxytryptamine(2B) receptor agonists: implications for drug safety assessment. Mol Pharmacol. 2009;76(4):710-22. 